\title{
IMPROVING TEACHER PERFORMANCE COMPETENCE IN TEACHING STUDENTS THROUGH TECHNOLOGY INFORMATION AND COMMUNICATIONS IN ELEMENTARY SCHOOL 30 TIMBULUN
}

\author{
SITI KAROMAH \\ Volume 1 Nomor 1 \\ JIPS ISSN: 2579-5449
}

\begin{abstract}
Basically the task of teachers to educate, teach, train and evaluate students, so that learners can become human beings who can carry out life in harmony with his nature as a human being. Related to the task of teachers in evaluating students then teachers should have the skills to teach.

It is therefore necessary for the principal's role to motivate teachers to improve their performance and objectives to help teachers clearly see the purpose of education and to achieve the educational goals by fostering and

developing better teaching methods and procedures.

The purpose of this research is to increase the competence of teachers in the use of ICTs, so that it can improve the performance and the performance of teachers in the world compete in this globalization.

So with the use of ICT teachers are able to access and create lesson material that is better and interesting so siswapun will have a better learning achievement also especially at SD Negeri 30 Timbulun.
\end{abstract}

Keywords: Teacher, Performance

\section{Peningkatan Kompetensi Kinerja Guru Dalam Mengajar Siswa Melalui Penggunaan Teknologi Informasi Dan Komunikasi Di Sekolah Dasar Negeri 30 Timbulun}

\begin{abstract}
ABSTRAK
Pada dasarnya tugas guru mendidik, mengajar, melatih serta mengevaluasi siswa, agar peserta didik dapat menjadi manusia yang dapat melaksanakan kehidupan selaras dengan

kodratnya sebagai manusia. berkaitan dengan tugas guru didalam mengevaluasi siswa maka guru hendaknya memiliki ketrampilan mengajar.
\end{abstract}


Untuk itu diperlukan peran kepala sekolah untuk memotivasi para guru untuk meningkatkan kinerjanya dan tujuannya untuk membantu guru-guru melihat dengan jelas tujuan pendidikan dan berusaha mencapai tujuan pendidikan itu dengan membina dan mengembangkan metode-metode dan prosedur pengajaran yang lebih baik.

Tujuan dari penelitian ini adalah ingin meningkatkan kompetensi guru dalam

\section{Kata kunci: kinerja guru}

\section{PENDAHULUAN}

Latar Belakang, Diberlakukannya kurikulum 2006 yang berbasis kompetensi lebih menekankan pada sains dan tehnologi, sehingga dalam pelaksanaannya dibutuhkan usaha guru yang bersifat ekstra. Guru harus mampu mengikuti siswa kompetitif yang memiliki kemampuan berpikir tinggi, dan tidak bersikap skeptis atau apatis terhadap siswa yang lemah dalam upaya menyerap materi pembelajaran. Di samping itu minat belajar yang dimiliki para siswa cukup heterogen. Guru sebagai fasilitator harus mampu memilih dan mengolah metode, strategi dan motif mengajar yang dapat meningkatkan minat belajar para peserta didik.

Dewasa ini teknologi dalam pendidikan berkembang pesat dan sangat membantu dalam kegiatan belajar mengajar. Baik dari segi administrasi guru sampai pembuatan media yang berbasis komputerisasi. Seperti tercantum secara eksplisit dalam Rencana Strategis Departemen Pendidikan Nasional 2005 - 2009, terlihat jelas bahwa TIK memainkan peran penting dalam menunjang tiga pilar kebijakan pendidikan nasional, yaitu: (1) perluasan dan pemerataan akses; (2) peningkatan mutu, relevansi dan daya saing; dan (3) penguatan tata kelola, akuntabilitas dan citra publik pendidikan, untuk mewujudkan pendidikan yang bermutu, akuntabel, murah, merata dan terjangkau rakyat banyak. penggunaan TIK, sehingga dapat meningkatkan prestasi dan kinerja guru dalam bersaing di dunia globalisasi ini. Maka dengan penggunaan TIK guru-guru mampu mengakses dan membuat materi pelajaran yang lebih baik dan menarik sehingga siswapun akan memliki prestasi belajar yang lebih baik juga terutama pada SD Negeri 30 Timbulun.

Tidak diragukan lagi peran TIK dalam berbagai aspek kehidupan. Hampir semua bidang mengaplikasikan TIK dalam setiap penyelesaian masalah. Untuk itu agar dapat menjalankan sistem atau operasi TIK dengan baik, diperlukan tenaga operasional yang handal dalam mengontrol sistem kerja peralatan TIK tersebut. Hal inilah yang mendasari pentingnya mempelajari TIK. Perlu diketahui bahwa TIK memiliki dua aspek, yaitu Teknologi Informasi dan Teknologi Komunikasi.

Teknologi Informasi, meliputi segala hal yang berkaitan dengan proses, penggunaan sebagai alat bantu, manipulasi, dan pengelolaan informasi. Sedangkan Teknologi Komunikasi merupakan segala hal yang berkaitan dengan penggunaan alat bantu untuk memproses dan mentransfer data dari perangkat yang satu ke lainnya. Oleh karena itu, Teknologi Informasi dan Teknologi Komunikasi adalah suatu padanan yang tidak terpisahkan yang mengandung pengertian luas tentang segala kegiatan yang terkait dengan pemrosesan, manipulasi, pengelolaan, dan transfer/pemindahan informasi antar media.

Di dalam sektor pendidikan, Kementerian Pendidikan dan Kebudayaan (Kemdikbud) juga telah menempatkan TIK sebagai salah -.... pendukung utama tersedianya lay: 80 pendidikan.Penyediaan tenaga pendidik 
berkompeten yang merata di seluruh Indonesia telah dinyatakan sebagai salah satu tujuan strategis dalam Renstra Pendidikan Nasional 2010 - 2014. Penyediaan pendidik yang menguasai kompetensi TIK merupakan kebutuhan mendesak demi tercapainya tujuan strategis dalam Renstra 2010 - 2014 tersebut.

Guru yang kompeten dalam pemanfaatan TIK diperlukan untuk mengembangkan kompetensi personal, pedagogis, sosial, dan professional sesuai dengan Permendiknas No 16 Tahun 2007 tentang Kompetensi Guru. Saat ini merupakan bangkitnya generasi emas yang menjadi landasan untuk mencapai generasi 2045 dan siswa yang cerdas dan kompetitif menjadi human capital dalam pembangunan sosial dan ekonomi, seperti yang disampaikan dalam sambutan Menteri Pendidikan pada Hari Pendidikan Nasional

Pada era sekarang ini semakin tinggi tuntutan untuk bisa menggunakan teknologi dalam dunia pendidikan. Karena peranannya sangat penting dalam membantu guru atau pendidik dalam menjalankan tugas dan fungsinya sebagai guru. Sebagai seorang guru sudah wajib untuk bisa menggunakan teknologi dalam bekerja. Seperti pada saat sekarang ini dalam pembuatan rencana pelaksanaan pembelajaran guru dituntut untuk membuat suatu rencana pembelajaran dengan ketikan.

Banyaknya perangkat pembelajaran yang harus dibuat guru secara kompuetrisasi akan menuntuk guru bisa menggunakan teknologi. Selain itu guru juga memiliki banyak admisnistrasi yang harus dikerjakan dengan teknologi komputerisasi. Dalam pembuatan media pembelajaran guru lebih mudah dengan adanya teknologi informasi dan komunikasi. Selain itu dalam pengolahan nilai atau data yang dibutuhkan guru akan lebih mudah dikerjakan. Baik dengan merekap nilai siswa, merengking nilai siswa maupun mengelompokan data - data yang penting. Adapun tugas guru tidak hanya mengajar semata, guru juga memiliki kompetensi utnuk membuat admistrasi sekolah. Untuk itu guru dituntut bisa menggunakan teknologi dalam pendidikan.

Hal diatas berbeda dengan apa yang terjadi di Sekolah Dasar Negeri No 30 Timbulun Guru yang mengajar di Sekolah Dasar Negeri No 30 Timbulun belum seluruhnya bisa dan mahir menggunakan teknologi dalam pembelajaran. Dalam pembuatan perangkat pembelajaran guru masih meminta bantuan orang lain dalam membuatnya secara komputerisasi. Kemampuan yang dimiliki guru dalam bidang teknologi belum begitu baik. Guru hanya sekedar bisa menghidupkan komputer dan dalam pengoperasiannya belum begitu sempurna dan baik.

Guru sekedar bisa mengetik saja dan kurang mampu mengatur margin dan toolbar yang ada pada komputer. Itupun guru baru pada Microsoft word saja, guru dalam hal ini masih pada taraf kurang bisa dalam penggunaan Microsoft word ini. Dalam pengolahan nilai dan data guru masih dalam bentuk manual, belum bisa menggunakan microrosoft excel. Pada hal dengan Microsoft excel ini guru bisa mengolah nilai dengan mudah dan cepat. Pada Microsoft excel ini hampir semua guru di Sekolah Dasar Negeri 30 Timbulun belum bisa menggunakannya. Hanya beberapa guru saja yang telah bisa.

Dalam pembuatan media pembelajaran yang standart dengan Microsoft power point guru di Sekolah Dasar Negeri 30 Timbulun belum bisa dengan baik. Dengan adanya media pembelajaran yang menarik akan membantu siswa dalam belajar dan dapat memotivasi siswa dalam belajar. Rata - rata guru yang belum bisa adalah guru - guru senior. Minat guru untuk mempelajari TIK sangat tinggi tetapi selama ini guru belum ada yang membina dan kurangnya program yang membantu guru untuk bisa mengmebangkan profesionalnya dalam bidang TIK.

Untuk mengatasi hal tersebut kepala sekolah Sekolah Dasar Negeri 30 Timbulun membimbing teman - teman guru disekolah untuk mempelajari TIK. Kepala sekolah memimbing guru dalam belajar mengeporesikan komputer khususnya padaMicrosoft Office. Dengan adanya hal tersebut akan d membantu guru dalam menyelesaikan peran 81 pembelajaran, mengolah data dan membuat media pembelajaran. Dengan materiMicrosoft Word yang dipelajari guru, akan bisa membantu 


\section{Journal Ilmiah Pendidikan Scholastic}

guru dalam bekerja menyangkut administrasi sekolah yang berupa laporan - laporan dan membuat perangkat pembelajaran seperti RPP, Silabus, Program tahunan dan guru bisa mengetik sesuai dengan apa yang diinginkan.

Dengan mampunya guru dalam menggunakan Microsoft Word ini guru bisa mengetik karya ilmiah berupa Penelitian Tindakan Kelas yang telah mereka buat. Dengan mempelajari Microsoft Excell guru akan mampu mengolah nilai secara otomatis dan cepat. Dalam pengolahan data - data lain guru juga akan lebih mudah mengerjakannya. Dengan menggunakan Microsoft Excell tampilan yang dibuat guru dalam mengolah nilai jauh lebih rapi dan baik dari pada dikerjakan manual.

Selain itu guru juga mempelajari Microsoft Power Point dengan bisanya guru menggunakan Microsoft Power point guru akan mudah membuat media pembelajaran yang menarik dan memudahkan guru menyajikan pembelajaran. Apalagi saat sekarang ini dengan hampir semua guru Sekolah Dasar Negeri 30 Timbulun memiliki laptop dan sekolahpun telah memiliki proyektor untuk penunjang proses pembelajaran.

Dengan adanya program yang dilakukan kepala sekolah dalam membimbing guru menngoperasikan komputer khususnya pada Microsoft Office akan membantu guru dalam peningkatan kompetensi guru pada era globalisasi seperti sekarang ini. TIK merupakan hal yang pokok pada saat sekarang ini. Hal ini merupakan salah satu bgain dari kompetensi guru. Salah satunya kompetensi professional. Seperti yang tertuang dalam Permendiknas No 16 tahun 2007 menyatakan aspek dari kompetensi profesionalisme adalah : 1) Menguasai materi, struktur, konsep, dan polapikir keilmuan yang mendukung mata pelajaran yang diampu, 2) Menguasai standar kompetensi dan kompetensi dasar mata pelajaran/bidang pengembangan yang diampu,

3) Mengembangkan materi pembelajaran yang diampu secara kreatif, 4) Mengembangkan keprofesionalan secara berkelanjutan dengan melakukan tindakan reflektif, 5) Memanfaatkan teknologi informasi dan komunikasi untuk berkomunikasi dan mengembangkan diri.

Dari beberapa aspek yang harus dimiliki oleh guru dalam kompetensi profesionalisme salah satunya memanfaatkan teknologi informasi dan komunikasi dan mengembangkan diri, dengan hal tesebut guru dituntut untuk terus mengembangkan diri dan memanfaatkan teknologi informasi dan komunikasi. Dengan mempelajari Microsoft Office guru telah mengembangkan diri dalam teknologi informasi dan komunikasi. Dengan hal tersebut akan membantu guru dalam menjalankan tugas dan fungsinya sebagai guru.

Berdasarkan penjelasan diatas kepala sekolah Sekolah Dasar Negeri 30 Timbulun tertarik melakukan Penelitian Tindakan Sekolah yang berjudul Peningkatan kompetensi guru dalam bekerja melalui Penggunaan TIK di Sekolah Dasar Negeri 30 Timbulun

Berdasarkan latar belakang diatas dapat di rumuskan masalah penelitian sebagai berikut : 1) Apakah dengan bimbingan belajar Teknologi Informasi dan Komunikasi (TIK) oleh kepala sekolah dapat meningkatkan kompetensi guru dalam penggunaan Teknologi Informasi dan Komunikasi (TIK). 2) Apakah penggunaan Teknologi Infomasi dan Komunikasi dapat membantu guru dalam bekerja di Sekolah Dasar Negeri 30 Timbulun 3) Bagaimanakah kompetensi guru pada penggunaan Teknologi Informasi dan Komunikasi (TIK) di Sekolah Dasar Negeri 30 Timbulun

Berdasarkan atas permasalahan yang diajukan, maka tujuan yang hendak dicapai dalam penelitian ini adalah: 1) Untuk mengetahui dampak bimbingan belajar Teknologi Informasi dan Komunikasi (TIK) terhadap peningkatan kompetensi guru dalam bidang Teknologi Informasi dan Komunikasi (TIK) 2) Untuk mengetahui kompetensi guru dalam bidang Teknologi Informasi dan Komunikasi (TIK) di Sekolah Dasar Negeri 30 Timbulun. 3) Untuk meningkatkan kompetensi guru dibidang Teknologi Informasi dan Komunikasi (TIK) di Sekolah Dasar Neger 82 Timbulun. 


\section{METODE PENELITIAN}

\begin{abstract}
Penelitian ini akan dilaksi di Sekolah Dasar Negeri 30 Tir Pemilihan tempat ini dimana penulis bc mengabdikan diri, yang mana selama in di Sekolah Dasar Negeri 30 Timbulun mampu mengoperasikan komputer.
\end{abstract}

Penelitian ini dilakukan pada siswa dan guru Sekolah Dasar Negeri 30 Timbulun. Penelitian akan dilakukan pada bulan Juli 2016 tahun ajaran 2016/2017. Waktu yang dibutuhkan untuk penelitian ini terdiri 2 siklus.

Pendekatan yang digunakan dalam penelitian ini adalah penekatan kuliatatif dan pendekatan kuatitatif. Dimana pendekatan kuantitatif data berupa angka - angka dan pendekatan kualitatif data berupa tulisan, gambar dan grafik.

Adapun penelitian yang akan diterapkan adalah Penelitian Tindakan Sekolah (PTS) adalah jenis penelitian yang dilakukan oleh kepala sekolah dan pengawas sekolah. Seperti yang dikemukakan Mulyasa bahawa Penelitian Tindakan Sekolah merupakan upaya peningkatan kinerja sistem pendidikan dan meningkatkan menejemen sekolah agar menjadi produktif, efektif dan efisien. jenis penelitian ini perlu diperkenalkan kepada kepala sekolah dan pengawas sekolah nelalui pendidikan dan pelatihan (diklat) PTS.

Dalam pelaksanaan diklat PTS, diharapkan kepala sekolah dan pengawas sekolah dapat: (1) memahami PTS sebagai bagian dari penelitian ilmiah, (2) memahami makna PTS,

(3) memahami penyusunan usulan PTS,

(4) melaksanakan dan melaporkan hasil PTS yang dilakukannya.

Menurut Direktorat Tendik (2008) Langkah - Langkah PTS terdiri atas empattahap,yaituplanning (Rencana), action (tin dakan), observasi (pengamatan)

dan reflection (refleksi). Siklus spiral dari tahaptahap PTS dapat sebagai berikut: 1. Rangangan/rencana awal, sebelum mengadakan penelitian peneliti menyusun rumusan masalah, tujuan dan membuat rencana tindakan, termasuk di dalamnya instrument penelitian dan perangkat pembelajaran
2. Tindakan dilakukan setelah rancangan disusun. Tindakan merupakan bagian yang akan dilakukan dalam Penelitian Tindakan Sekolah dalam penelitian 3. Pengamatan dilakukan waktu guru di bombing menggunakan komputer.

Data yang dikumpulkan dapat berupa data pengelolaan sekolah. Instrumen yang umum dipakai adalah lembar observasi,dan cacatan lapangan yang dipakai untuk memperoleh data secara objektif yang tidak dapat terekam melalui lembar observasi, misalnya aktivitas siswa selama pemberian tindakan berlangsung, reaksi mereka, atau pentunjuk-petunjuk lain yang dapat dipakai sebagai bahan dalam analisis dan untukkeperluan refleksi 4. Refleksi, peneliti mengkaji melihat dan mempertimbangkan hasil atau dampak dari tindakan yang dilakukan berdasarkan lembar pengamatan yang diisi oleh pengamat

Penelitian ini dilakukan dengan menggunakan model siklus yang dikembangkan oleh Kemmis dan Mc Taggart (dalam Ritawati, 2008:69). Proses penelitian merupak proses daur ulang atau siklus yang dimulai aspek , mengembangkan perencanaan, melakukan observasi terhadap tindakan dan melakukan refleksi terhadap perencanaan kegiatan tindakan dan kesuksesan hasil yang diperoleh.

Pada setiap akhir tindakan dinilai dengan instrument bimbingan setelah belajar. Alur penelitian yang dilakukan dapat digambarkan seperti bagan berikut

Tahap perencanaan ini berupa rencana kegiatan menentukan langkah-langkah yang akan dilakukan peneliti untuk memecahkan masalah. Langkah ini merupakan upaya memperbaiki kekurangan guru dalam menggunakan komputer kegiatan yang akan dilakukan adalah (1) menyusun jadwal bimbingan belajar, (2) membuat dan meyiapkan instrumen penelitian berupa lembar obser 83 memperoleh data nontes, (3) menyial refleksi dan perbaikan guru dalam mengajar.

Tindakan adalah aktivitas yang dirancang dengan sistematis untuk menghasilkan adanya peningkatan atau perbaikan dalam proses pembelajaran, sehingga proses pembelajaran di 
lakukan guru lebih maksimal dan baik sehingga pembelajaran

Dengan adanya bimbingan belajar TIK guru bisa meningkatkan kemampuannya dalam mengajar dan menguasai knmpetensi kompetensi guru secara keseluruhan. Dengan hal ini guru akan mudah dalam mengerjakan admistrasi yang menyakut dengan tugas pokoknya

Observasi adalah mengamati hasil atau dampak dari tindakan-tindakan yang dilakukan guru dalam bimbingan belajar TIK. Observasi dilaksanakan peneliti selama kegiatan berlangsung . Observasi meliputi observasi guru menngunakan komputer .

Refleksi adalah mengkaji, melihat, dan mempertimbangkan hasil atau dampak dari tindakan. Berdasarkan hasil refleksi ini, peneliti dapat melakukan revisi terhadap rencana selanjutnya atau terhadap rencana awal siklus II.

Pada tahap ini, peneliti menganalisis hasil kemampuan guru dalam mengajar siklus I. Jika kemampuan tersebut belum memenuhi nilai target yang telah ditentukan, akan dilakukan tindakan siklus II dan masalah-masalah yang timbul pada siklus I akan dicarikan alternatif pemecahannnya pada siklus II.

Data penelitian ini berupa hasil observasi dan dokumentasi dari setiap tindakan perbaikan pada pembelajaran yang di sajikan guru Sekolah Dasar Negeri 30 Timbulun. Data tersebut berkaitan dengan perencanaan, pelaksanaan dan hasil pembelajaran berupa informasi sebagai berikut: a. Rencana pelaksanaan bimbingan. b. Pelaksanaan bimbingan TIK

c. Evaluasi dari kemampuan guru dalam menggunakan komputer. d. Hasil pengamatan guru dalam menggunakan komputer

Sumber data dari penelitian ini berdasarkan pengamatan terhadap kemampuan guru dalam menggunakan komputer melalui bimbingan belajar penggunaan TIK pada guru Sekolah Dasar Negeri 30 Timbulun.

Teknik penelitian dilakukan dengan cara melihat kekurangan guru dalam menggunakan TIK. Selain itu teknik yang dilakukan dalam penelitian ini adalah dengan cara melakukan observasi oleh Kepala Sekolah terhadap guru dalam mengoperasikan komputer
Setelah instrument ini diisi hasil data berupa tes yang diperoleh diolah. Sehingga di dapatkan data yang valid. Dengan hal ini bisa dilihat sejauh mana kemampuan guru dalam menggunakan TIK melalui bimbingan belajar oleh kepala sekolah

Instrumen penelitian adalah alat yang digunakan untuk mengumpulkan data, berupa panduan observasi (pengamatan). dan tes.

Menurut Anas Sudjijono (2011:76) adalah "cara menghimpun bahan - bahan keterangan (data) yang dilakukan dengan mengadakan pengamatan dan pencatatan secara sistematis terhadap fenomena - fenomena yang sedang dijadikan sasaran pengamaatan" Lembaran Pengamatan/Observasi, digunakan untuk mengamati proses pembelajaran yang berlangsung di kelas. Hal-hal yang dinilai dengan menggunakan lembaran pengamatan ini adalah: 1) kemampuan guru dalam menggunakan komputer dari semua aspek yang telah ditetapkan.

Data yang diperoleh dalam penelitian dianalisis dengan menggunakan model analisis data kualitatif sesuai dengan yang dikemukakan oleh Rochiati (2007:135) yakni analisis data dimulai dengan menelaah sejak pengumpulan data sampai seluruh data terkumpul. Data tersebut direduksi berdasarkan masalah yang diteliti, diikuti penyajian data dan terakhir penyimpulan atau vertifikasi. Tahap analisis yang demikian dilakukan berulang-ulang begitu data selesai dikumpulkan pada setiap tahap pengumpulan data dalam setiap tindakan.

Tahap analisis data tersebut adalah sebagai berikut: 1 . Menelaah data yang sudah terkumpul baik melalui observasi dan tes kemampuan guru dalam menggunakan komputer dengan melakukan proses transkripsi hasil pengamatan, penyeleksiaan dan pemilihan data. Seperti pengelompokan data pada siklus I, siklus II dan seterusnya. Kegiatan menelaah 184 dilaksanakan sejak awal data dikumpul

2. Reduksi data meliputi pengkategorian pengklasifikasian. Semua data yang telah terkumpul diseleksi dan dikelompokan sesuai dengan penelitian. Data yang telah dipisahpisahkan tersebut lalu diseleksi mana yang relevan dan mana yang tidak relevan. Data yang 


\section{Journal Ilmiah Pendidikan Scholastic}

relevan akan dianalisis sedangkan yang tidak relevan tidak dibahas. 3. Menyajikan data dilakukan dengan cara mengorganisasikan informasi yang sudah direduksi. Data tersebut mula-mula disajikan terpisah tetapi setelah tindakan terakhir direduksi keseluruhan data tindakan dirangkum dan disajikan secara terpadu. 4. Menyimpulkan hasil penelitian tindakan ini merupakan penyimpulan akhir penelitian. Kegiatan ini dilakukan dengan cara peninjauan kembali lembaran pengamatan, dan hasil tes guru menggunakan komputer.

Analisis data dilakukan terhadap data yang telah direduksi baik data perencanaan, pelaksanaan maupun data evaluasi. Hal ini dimasukkan agar dapat ditemukan berbagai informasi yang spesifik dan terfokus pada berbagai informasi yang mendukung pembelajaran dan yang menghambat pembelajaran. Dengan demikian pengembangan dan perbaikan atas berbagai kekurangan dapat dilakukan tepat pada aspek yang bersangkutan. Hasil penelitian ini, selain berbentuk narasi juga berbentuk angka dan bilangan. Jadi, dalam pengolahan datanya juga digunakan analisis data kuantitatif.

\section{HASIL DAN PEMBAHASAN PENELITIAN}

Kinerja guru yang ditunjukkan dapat diamati dari kemampuan guru dalam melaksanakan tugas dan tanggung jawabnya yang tentunya sudah dapat mencermikan suatu pola kerja yang dapat meningkatkan mutu pendidikan kearah yang lebih baik. Seseorang akan bekerja secara profesional bilamana memiliki kemampuan kerja yang tinggi dan kesungguhan hati untuk mengerjakan dengan sebaik-baiknya. Sebaliknya, seseorang tidak akan bekerja secara profesional bilamana hanya memenuhi salah satu diantara dua persyaratan di atas.

Jadi betapapun tingginya kemampuan seseorang, ia tidak akan bekerja secara profesional apabila tidak memiliki kepribadian dan dedikasi dalam bekerja yang tinggi. Guru yang memiliki kinerja yang baik tentunya memiliki komitmen yang tinggi dalam pribadinya artinya tercermin suatu kepribadian dan dedikasi yang paripurna. Tingkat komitmen guru terbentang dalam satu garis kontinum, bergerak dari yang paling rendah menuju paling tinggi.

Guru yang memiliki komitmen yang rendah biasanya kurang memberikan perhatian kepada murid, demikian pula waktu dan tenaga yang dikeluarkan untuk meningkatkan mutu pembelajaran yang sangat sedikit. Sebaliknya seseorang guru yang memiliki komitmen yang tinggi biasanya tinggi sekali perhatiannya dalam bekerja. Demikian pula waktu yang disediakan untuk peningkatan mutu pendidikan sangat banyak. Sedangkan tingkat abstraksi yang dimaksudkan di sini adalah tingkat kemampuan guru dalam mengelola pembelajaran, mengklarifikasi masalah-masalah pembelajaran, dan menentukan alternatif pemecahannya.

Hal tersebut sesuai dengan pendapat Glickman (dalam Bafadal I, 2003) yang menyatakan bahwa "guru yang memiliki tingkat abstraksi yang tinggi adalah guru yang mampu mengelola tugas, menemukan berbagai permasalahan dalam tugas dan mampu secara mandiri memecahkannya".

Langkah strategis dalam upaya meningkatkan kinerja guru dapat dilakukan melalui beberapa terobosan antara lain : Kepala Sekolah harus memahami dan melakukan tiga fungsi sebagai penunjang peningkatan kinerja guru antara lain : a) Membantu guru memahami, memilih dan merumuskan tujuan pendidikan yang dicapai. b) Mendorong guru agar mampu memecahkan masalah-masalah pembelajaran yang dihadapi dan dapat melihat hasil kerja 85 c) Memberikan pengakuan atau penghar: terhadap prestasi kerja guru secara layak, yang diberikan oleh kepala sekolah maupun yang diberikan semasa guru, staf tata usaha, siswa, dan masyarakat umum maupun yang diberikan 


\section{Journal Ilmiah Pendidikan Scholastic}

pemerintah. d) Mendelegasikan tanggung jawab dan kewenangan kerja kepada guru untuk mengelola proses belajar mengajar dengan memberikan kebebasan dalam perencanaan, pelaksanaan dan evaluasi hasil belajar. e) Membantu memberikan kemudahan kepada guru dalam proses pengajuan kenaikan pangkatnya sesuai dengan peraturan yang berlaku. Membuat kebijakan sekolah dalam pembagian tugas guru, baik beban tugas mengajar, beban administrasi guru maupun beban tugas tambahan lainnya harus disesuaikan dengan kemampuan guru itu sendiri. Melaksanakan tehnik supervisi yang tepat sesuai dengan kemampuannya dan sesuai dengan keinginan guru-guru secara berkesinambungan dalam upaya memperbaiki dan meningkatkan kemampuan guru dalam proses pembelajaran. Mengupayakan selalu meningkatkan kesejahteraannya yang dapat diterima guru serta memberikan pelayanan sebaik-baiknya. Menciptakan hubungan kerja yang sehat dan menyenangkan dilingkungan sekolah baik antara guru dengan kepala sekolah, guru dengan guru, guru dengan siswa, guru dengan tata usaha maupun yang lainnya. Menciptakan dan menjaga kondisi dan iklim kerja yang sehat dan menyenangkan di lingkungan sekolah, terutama di dalam kelas, tempat kerja yang menyenangkan, alat pelajaran yang cukup dan bersifat up to date, tempat beristirahat di sekolah yang nyaman, kebersihan dan keindahan sekolah, penerangan yang cukup dan masih banyak lagi. Memberikan peluang pada guru untuk tumbuh dalam meningkatkan pengetahuan, meningkatkan keahlian mengajar, dan memperoleh keterampilan yang baru. Mengupayakan adanya efek kerja guru di sekolah terhadap keharmonisan anggota keluarga, pendidikan anggota keluarga, dan terhadap kebahagiaan keluarganya. Mewujudkan dan menjaga keamanan kerja guru tetap stabil dan posisi kerjanya tetap mantap sehingga guru merasa aman dalam pekerjaannya. Memperhatikan peningkatan status guru dengan memenuhi kelengkapan status berupa perlengkapan yang mendukung kedudukan kerja guru, misalnya tersediahnya ruang khusus untuk melaksanakan tugas, tempat istirahat khusus, tempat parkis khusus, kamar mandi khusus dan sebagainya. ( Junaidin, 2006). Menggerakkan guru-guru, karyawan, siswa dan anggota masyarakat untuk mensukseskan programprogram pendidikan di sekolah. Menciptakan sekolah sebagai lingkungan kerja yang harmonis, sehat, dinamis dan nyaman sehingga segenap anggota dapat bekerja dengan penuh produktivitas dan memperoleh kepuasan kerja yang tinggi.

Langkah lain yang dilakukan oleh sekolah untuk meningkatkan kinerja guru melalui peningkatan pemanfaatan teknologi informasi yang sedang berkembang sekarang ini dan mendorong guru untuk menguasainya. Melalui teknologi informasi yang dimiliki baik oleh daerah maupun oleh individual sekolah, guru dapat melakukan beberapa hal diantaranya : (1) melakukan penelusuran dan pencarian bahan pustaka, (2) membangun Program Artificial Intelligence (kecerdasan buatan) untuk memodelkan sebuah rencana pengajaran, (3) memberi kemudahan untuk mengakses apa yang disebut dengan virtual clasroom ataupun virtual university, (4) pemasaran dan promosi hasil karya penelitian.

Dengan memanfaatkan teknologi informasi maka guru dapat secara cepat mengakses materi pengetahuan yang dibutuhkan sehingga guru tidak terbatas pada pengetahuan yang dimiliki dan hanya bidang studi tertentu yang dikuasai tetapi seyogyanya guru harus mampu menguasai lebih dari bidang studi yang ditekuninya sehingga bukan tidak mungkin suatu saat guru tersebut akan mendalami hal lain yang masih memiliki hubungan erat dengan bidang tugasnya guna meningkatkan kinerja ke arah yang lebih baik.

Dinas Pendidikan setempat selaku pihak yang ikut andil dalam mengeluarkan dan memutuskan kebijakan pada sektor pendid 86 dapat melakukan langkah sebagai berikı Memberikan kemandirian kepada sekolah se utuh. Mengontrol setiap perkembangan sekolah dan guru. Menganalisis setiap persoalan yang muncul di sekolah Menentukan alternatif pemecahan bersama dengan kepala sekolah dan guru terhadap persoalan yang dihadapi guru 


\section{Journal Ilmiah Pendidikan Scholastic}

Kinerja guru tidak dapat berdiri sendiri melainkan sangat dipengaruhi oleh faktor lain melalui interaksi sosial yang terjadi di antara diri mereka sendiri maupun dengan komponen yang lain dalam sekolah. Hal lain yang dapat dilakukan adalah melalui peningkatan moral kerja guru. Moral kerja sebagai suatu sikap dan tingkah laku yang merupakan perwujudan suatu kemauan yang dibawa serta ke sekolah dan kerjannya. Pemahaman tentang moral kerja yang belum sempurna menyebabkan tidak dapat mempengaruhi kinerja secara spesifik.

Padahal moral kerja yang tinggi dapat meningkatkan semangat untuk bekerja lebih baik. Moral kerja dapat pula dipengaruhi oleh motif-motif tertentu yang bersifat subyektif maupun obyektif. Adapun yang menjadi motif untuk bekerja lebih baik adalah kebutuhankebutuhan (needs) yang menimbulkan suatu

\section{PENUTUP}

Untuk memperoleh keberhasilan pendidikan, keberadaan profesi guru sangat penting untuk diperhatikan dan ditingkatkan dalam hal ini kinerja guru sebab kinerja guru merupakan kemampuan yang ditunjukan oleh seorang guru dalam melaksanakan tugas dan pekerjaannya dengan penggunaan TIK di Sekolah Dasar Negeri 30 Timbulun. Kinerja guru dapat diamati melalui unsur perilaku yang ditampilkan guru sehubungan dengan pekerjaan dan prestasi yang dicapai berdasarkan indikator kinerja guru.

Kinerja guru sangat dipengaruhi oleh beberapa faktor antara lain :pertama faktor kepribadian dan dedikasi yang tinggi menentukan keberhasilan guru dalam melaksanakan tugasnya yang tercermin dari sikap dan perbuatannya dalam membina dan membimbing peserta didik;

Kedua faktor pengembangan profesional guru sangat penting karena tugas dan perannya bukan hanya memberikan informasi ilmu pengetahuan melainkan membentuk sikap dan jiwa yang mampu bertahan dalam era hiperkompetisi; tindakan perbuatan yang menimbulkan suatu perbuatan (behaviour) yang bertujuan untuk memenuhi kebutuhan-kebutuhan tersebut (goals).

Implikasi pandangan ini, kegiatan mengajar yang lazim perlu dimodifikasi dan diubah. Misalnya pada kegiatan mengajar sains, tidak cukup hanya melalui telling science tetapi perlu mengembangkan kegiatan yang bersifat doing science atau kegiatan-kegiatan yang mendorong siswa untuk mengembangkan thinking skill dan bahkan tidak hanya memperluas wawasan kognitif tetapi juga menyentuh ranah afektif, psikomotor, dan juga metakognitif. Ranah yang terakhir ini para ahli pendidikan sering menyebutnya sebagai kemampuan tentang 'belajar bagaimana belajar' (learn how to learn

Ketiga faktor kemampuan mengajar guru merupakan pencerminan penguasaan guru atas kompetensinya;

Keempat faktor hubungan dan komunikasi yang terjadi dalam lingkungan kerja memberikan dukungan bagi kelancaran tugas guru di sekolah;

kelima faktor hubungan dengan masyarakat, peran guru dalam mendukung kegiatan hubungan sekolah dengan masyarakat dapat meningkatkan pemahaman masyarakat tentang tujuan serta sasaran yang ingin direalisasikan sekolah;

Keenam faktor kedisiplinan, Suatu pekerjaan akan menuai hasil yang memuaskan semua pihak bila guru mampu mentaati ramburambu yang ditentukan melalui penerapan sikap disiplin dalam menjalankan tugasnya;

ketujuh faktor tingkat kesejahter memberikan insentif yang pantas sebagai wI memperbaiki tingkat kesejahteraan guru $\delta$..... mencegah guru melakukan kegiatan membolos karena mencari tambahan di luar untuk memenuhi kebutuhan hidup; dan kedelapan 


\section{Journal Ilmiah Pendidikan Scholastic}

faktor iklim kerja yang kondusif memberikan harapan bagi guru untuk bekerja lebih tenang sesuai dengan tujuan sekolah.

Guru merupakan ujung tombak keberhasilan pendidikan sehingga perlu melakukan upaya pembenahan baik secara internal maupun eksternal maka hal yang harus dipenuhi oleh guru dengan memahami dan mengusai kompetensi dasar yang dipersyaratkan. Dalam proses pembelajaran dalam koridor Kurikulum Berbasis Kompetensi sangat didukung oleh kemampuan guru dalam memperhatikan beberapa hal yang berkaiatan dengan pendekatan pembelajaran ala KBK diantaranya perkembangan anak, kemandirian anak, vitalisasi model hubungan demokratis, vitalisasi jiwa eksploratif, Kebebasan, menghidupkan pengalaman anak, keseimbangan perkembangan aspek personal dan sosial dan kecerdasan emosional.
Peningkatan mutu pendidikan tidak hanya melakukan perbaikan pada kualitas guru dalam melaksanakan proses belajar mengajar tetapi juga perlu dan penting diikuti dengan penataan manajemen pendidikan yang mengarah pada peningkatan kinerja guru melalui optimalisai peran sekolah dalam hal ini kepala sekolah dan pihak dinas pendidikan setempat untuk memberikan rasa nyaman bagi guru dalam melaksanakan tugasnya.

Selain itu optimalisasi kegiatan penataran harus betul-betul menyetuh kebutuhan guru agar bermanfaat bagi peningkatan kualitas proses belajar mengajar dan kualitas hasil belajar siswa sehingga kedepan kegiatan pelatihan dan semacamnya harus mampu diprogramkan supaya tidak tumpang tindih dan tidak mengganggu kegiatan belajar mengajar sebagai dampak guru mengikuti kegiatan tersebut.

\section{DAFTAR PUSTAKA}

Adiningsih N, 2002. Kualitas dan Profesionalisme Guru. Pikiran Rakyat 15 Oktober 2002.

Akadum. 1999. Potret Guru Memasuki Milenium Ketiga. Suara Pembaharuan. (Online)

Arifin, I. 2000. Profesionalisme Guru: Analisis Wacana Reformasi Pendidikan dalam Era Globalisasi. Simposium Nasional Pendidikan di Universitas Muhammadiyah Malang.

Arikunto, S. 1993. Manajemen Pengajaran Secara Manusiawi, Jakarta: PT. Rineka Cipta.

As'ad, Moh. 1995. Psikologi Industri. Yogyakarta: Liberty.

Badrun, A. 2005. Prospek Pendidikan dan tenaga kerja (guru) di kabupaten Dompu. Orasi Ilmiah disampaikan pada saat wisuda mahasiwa Diploma Dua program
PGSD/MI-PGTK/RA STAI Al-Amin Dompu

Brent D. Ruben. 1988. Communication and Human Behavior. New York: Macmilland Publishing Company.

Danim S., 2002. Inovasi Pendidikan. Bandung: CV. Pustaka Setia.

Daryanto, 2001. Administrasi Pendidikan, Jakarta: Rineka Cipta.

Davis, K. \& Newstrom, J.W,. 1996. Perilaku dalam Organisasi, Edisi ketujuh. Jakarta: Penerbit Erlangga.

Dedi Supriyadi, 1999. Mengangkat Citra c 88 Martabat Guru.. Yogyakarta: Adis Karya Nusa.

Denny Suwarja, 2003. KBK, tantangan profesionalitas guru. 19 Juli 2003. Artikel. Homepage Pendidikan Network 


\section{Journal Ilmiah Pendidikan Scholastic}

Depdiknas, 2005. Pembinaan Profesionalisme Tenaga pengajar (Pengembangan Profesionalisme Guru). Jakarta: Direktorat Jenderal Pendidikan dasar dan Menengah Direktorat Pendidikan Lanjutan Pertama Depdiknas.

Departemen Agama RI, 2003. Profesionalisme Pengawas Pendais. Jakarta: Direktorat Jenderal kelembagaan Agama Islam Depag RI.

Djamarah, S.B. 1994. Prestasi belajar dan Kompetensi Guru. Surabaya. Usaha Nasional.

Furkan, Nuril, 2006. Perubahan Paradigma Guru dalam Konteks KBK. Orasi Ilmiah pada Wisuda Diploma Dua Program PGSD/MI-PGTK/RA dan Dies Natalis STAI Al-Amin Dompu.

Good, V. Carter, 1959. Dictionary of Education, New York: McGraw-Hill Book Company.

Gunawan, 1996.

Administrasi

Sekolah. Jakarta: Rineka Cipta.
Drost. 1998. Sekolah: Mengajar atau Mendidik ?. Yogyakarta: Kanisius.

Fatah, N. 1996. Landasan Manajemen Pendidikan. Bandung: Remaja Rosdakarya.

Forsdale, 1981. Perspectives on Communication. New York: Random House.

Freud,S., 1950. The ego and the id. London: The Hogarth Press

Hasan, Ani M, 2001. Pengembangan Profesionalisme Guru di Abad Pengetahuan, 13 Juli 2003. Artikel. Homepage Pendidikan Network.

Hoy \& Miskel, 1987. Education Administration.: Theory, Research and Practice. New York: Random Hause.

Idris, J, 2005. Kompilasi Pemeikiran Pendidikan,. Taufiqiyah Sa'adah Banda Aceh dan Suluh Press Yogyakarta: Banda Aceh dan Yogyakarta. 